\title{
血液透析装置にオゾンを用いた消毒方法の試み
}

\author{
廣瀬 伸 彦*1 高橋 雅 彦*1 吉 本 裕*1 利 光 由 紀*1 \\ 田中 愛*1 尾崎泰史*1 戸浦 じゅん*1 御 園 陽 一*1 \\ 菅野有造*2 芝本隆*2 桑原道雄*2 小笠原陽*1 \\ 聖水会小笠原クリニック*1 東京医科歯科大学医学部附属病院血液浄化療法部*2
}

key words：血液透析装置，オゾン，洗浄消毒，透析液清浄化，環境污染

〈要旨〉

【目的】血液透析装置の消毒は主に次亚塩素酸ナトリウムが使用されるが，消毒排液の環境污染に対する影響が問 題となっている。 そこで残留性がなく, 環境污染に対する影響の少ないオゾンが血液透析装置の消毒剤として期待 される。われわれはオゾンが血液透析装置の消毒剂として有用か否かを基礎, 臨床の両面から評価した.【方法】基 礎：オゾンの安定性を電解質と有機物の添加試験から評価した。また, 血液透析装置内でのオゾン濃度の安定性を 観察し, 装置プライミングボリュームとオゾン濃度減衰の関係を実験的に評価した。ささらに, 透析液清浄化目的で 使用される精密濾過膜へのオゾン水暴露試験を行った。臨床：個人用透析装置にオゾン水消毒を 6 週間施行し透析 液エンドトキシン濃度, 細菌数を測定した。 また, あわせて装置内の水経路各部位を肉眼的に観察した。消毒行程 は, 前水洗 30 分, オゾン水消毒 30 分, 後水洗 30 分とした. 対象に週 1 回次亜塩素酸ナトリウム消毒と酶酸洗浄を 組み合わせた併用消毒を行った。【結果】基礎： $\mathrm{NaCl}$ ，アルブミンの添加でオゾン濃度は減衰した。透析装置内でオ ゾン濃度は減衰し, 密閉系出口部で最も濃度減衰が大きかった。精密濾過膜PEPA, PS はオゾン水で破壊された。 臨床：オゾン水消毒 6 週目に装置内にタンパク付着を認め, 弚れに伴い装置内のオゾン濃度減衰は高值となった。 併用消毒では装置内の各部位に付着物は全く認めず，装置内でのオゾン濃度減衰はなかった，透析液中のエンドト キシン濃度, 細菌数は通常の次亜塩素酸ナトリウム消毒時と同程度であった。【結語】基礎および臨床評価から考え ると現状ではオゾン水単体での血液透析装置消毒に限界を感じる。しかし, 他の洗浄剤・消毒剤との組み合わせや 洗浄消毒工程の変更, また装置内液流路構造の設計変更などの再検討により解決可能と思われた。 したがって, 血 液透析装置の消毒剤としてオゾンを用いる有用性は高いと考える.

\section{Evaluation of a disinfection method by using ozone for a single patient dialysis machine}

Nobuhiko Hirose*1, Masahiko Takahashi*1, Yutaka Yoshimoto*1, Yuki Toshimitsu*1, Ai Tanaka*1, Yasushi Ozaki*1, Jun Toura*1, Yoichi Misono*1, Yuzo Kan-no*2, Takashi Shibamoto*2, Michio Kuwahara*2, Minami Ogasawara*1

The Seisuikai Foundation, Ogasawara Clinic*1 ; Department of Blood Purification, Tokyo Medical and Dental University*2

Purpose : Dialysis machines are mainly disinfected using sodium hypo-chloride chemical solution, but the polluting effects of this discarded sodium on the environment are a problem. There is hope that ozone, which leaves no residue and has few harmful effects on the environment, may be useful as a disinfectant for dialysis machines. We evaluated whether ozone can be used as a dialysis machine disinfectant by both in vitro and clinical studies.

Methods : 1) In vitro study: The stability of ozone was evaluated in an experiment in which electrolytes and proteins were added. We observed the stability of ozone concentrations within the dialysis machines and experimentally evaluated the relationship between dialysis machine priming volume and ozone concentration

廣瀬 伸彦 聖水会小笠原クリニック テ 101-0041 東京都千代田区神田須田町 2-6 坂下ビル $7 \mathrm{~F}$

Nobuhiko Hirose Tel :03-3254-1199 Fax :03-3254-1189 E-mail : m6876tj $262 \mathrm{t} @$ asahi-net.or.jp

〔受付：平成 15 年 8 月 21 日, 受理：平成 15 年 11 月 17 日) 
attenuation. We also evaluated the effect of ozone exposure on the micro filter membranes that are used for dialysate purification. 2) Clinical study: We disinfected individual dialysis machines with ozone solution disinfectant for six weeks, and measured dialysate endotoxin concentrations and colonies count. Also, we macroscopically observed each water pathway site within the dialysis machine. The disinfecting procedure involved pre-rinsing for 30 minutes, ozone solution disinfecting for 30 minutes, and post-rinsing for 30 minutes. Combination disinfecting with sodium hypo-chloride and acetic acid rinsing was also performed once a week.

Results : 1) The ozone concentration decreased when $\mathrm{NaCl}$ and albumin were added. The ozone concentration decreased within the dialysis machine, with the greatest attenuation of concentration at the closed outlet. The ozone solution destroyed the micro filter membranes PEPA and PS. 2) After six weeks of ozone solution disinfecting, protein was seen to have adhered to the inside of the dialysis machine and the decreased ozone concentration inside the dialysis machine had become marked. After combination disinfecting, nothing was found adhering to the inside of the dialysis machine at any site, and the ozone concentration within the dialysis machine had not decreased. The endotoxin concentration and colonies count in dialysate were the same as those after hypo-chloride disinfecting was performed.

Summary : On fundamental in vitro as well as clinical evaluations, it was shown that there are limits to dialysis machine disinfecting with ozone solution alone. However, it was thought that these limits could be resolved by combining with other detergents/disinfectants, by re-examining modifications to the rinsing and disinfecting process, or by modifications to the design of the structure of the liquid pathway within the dialysis machine. The utility of ozone as a disinfectant for dialysis machine is therefore considered high.

\section{緒 言}

血液透析装置（透析装置）の消毒，洗浄の目的は血 液側から透析膜を介して透析液側に排液された物質に よる細菌やウィルス感染 (装置内污染), 透析液に由来 する炭酸カルシウム付着等装置内のトラブルを未然に 防ぐことにある ${ }^{1)}$. 最近は透析膜の大孔径化や性能の 向上で従来の透析膜に比較し，透析液側へのタンパク 漏出量増加や, 透析液中に微粒子などが存在した場合, 逆濾過現象 ${ }^{2}$ により血液側に移行することが懸念され はじめた3).したがって, 透析装置の消毒は今後ますま す重要視されなければならない。一方, 透析装置消毒 時に排液される消毒剤の環境污染も社会的問題であ る $^{4,5)}$.

現状の消毒剤は, 細菌, ウィルスに対し広いスペク トルを有し，コストの面でも優れる次亜塩素酸ナトリ ウムが主に使用される。しかし，次巠塩素酸ナトリウ ムを含んだ排水は浄化槽内の微生物を死滅させる原因 となることや，取り扱いの誤りによる毒性の強い塩素 ガスの発生, 微量の残留による人体や環境污染などの 問題が残る。最近, 透析装置の消毒剤として, 消毒排 液が短時間で酸素や水などの無害な物質に分解され, 環境に対する悪影響が少ない過酢酸系消毒剤や電解酸 性水等の利用が検討されはじめた ${ }^{6,7)}$.

今回検討したオゾンは自然界に存在する物質であり 消毒効果を発現した後，速やかに酸素に分解される.
したがって排液中や大気中に長時間残留しないため環 境污染が少ない8)。われわれはこのように環境に優し いオゾンを用い透析装置の消毒が可能か否か基礎拉よ び臨床の両面から検討し有用性を評価した。

\section{I 、オゾンとは}

オゾンは酸素の同素体で一般には地球を覆うオゾン 層の構成物質として知られている。酸素原子 3 個で構 成され，語源はギリシャ語で「におい」という意味を 持ち，その名の通り特有な臭気を持っている。基本的 には無色だが，高濃度になると微青色を示す。

オゾンは不安定物質のため速やかに分解し最終的に は酸素に戻る。その分解時に発生する酸素原子は自然 界ではフッ素に次いで強い酸化力を持ち, その酸化力 によって殺菌・脱臭・漂白などの効果を示す9).

\section{1. オゾン製造方法}

オゾン発生原理は酸素分子にエネルギーを与えて酸 素原子へ分解し，この酸素原子が酸素分子に結合する ことでオゾンとなる。利用されるエネルギーは電気や 紫外線などがある。製造方法は空気や酸素から作る放 電法や紫外線法, また水道水や電解液から作る電解法 などがある。

オゾン水とはオゾンそのものが液化したものではな く, 放電法や電解法により作られたオゾンガスを微細 な泡にして水に混入し溶解させたものである。オゾン ガスの水中への溶解方法は, 気泡溶解法, 隔膜溶解法, 
表 1 材料の耐オゾン性

\begin{tabular}{l|l}
\hline \multicolumn{1}{c|}{ オゾンに強い } & \multicolumn{1}{c}{ オゾンに弱い } \\
\hline ガラス, セラミック & 鉄, ニッケル \\
ステンレス, チタン & ポリエチレン, ポリプロピレン \\
テフロン, 塩化ビニル & ナイロン, ポリスルホン \\
フッ素ゴム, バイトン & 天然ゴム, ブチルゴム \\
ハイパロン & \\
\hline
\end{tabular}

充填層溶解法などがある。

\section{2.オゾンの特徵}

1) 殺菌効果

オゾンの殺菌作用やウィルス不活化作用は, 微生物 の細胞や粒子の構成成分を直接オゾンが酸化分解し, その結果細菌やウィルスは著しい変性・障害を受け て，増殖や生存が不能になる。抗生物質などのように 細胞内の代謝を阻害するものとは異なり細胞壁や, 細 胞質に存在する核酸も酸化分解されるため, 薬剤耐性 菌を作りにくい，さらに，殺菌力は芽胞に対しても比 較的短時間で効果がみられサルモネラ, MRSA, 大腸 菌では濃度 $4 \mathrm{ppm}$ のオゾン水で 30 秒以内にほほ死滅 すると報告されている ${ }^{10)}$.

2 ) 残留性

オゾンの半減期は安定状態の場合, 空気中で約 12 時 間, 水中で約 40 分といわれ極めて短時間に分解され る。一方, 当該気体中や液体中で，オゾンに対する反 応物が存在する場合では数秒でそれらの物質と反応し 酸素に戻る.オゾン水の場合その安定性は水温と $\mathrm{pH}$ に左右され，一般に水温， $\mathrm{pH}$ ともに低值で安定する.

\section{3 ）材料への影響}

多くの材料はオゾンの影響を受けにくいが天然ゴ ム，鉄，ポリエチレンなどの酸化しやすい材料では材 質の劣化が起こる ${ }^{11)}($ 表 1)。

4 ）環境への影響

オゾンは分解が速いため他の薬剤と比較しても，そ の消毒排水が処理槽や下水道に与える悪影響すなわち 環境污染は皆無㳊しい.さ等しに排液中の BOD, COD の低隇効果が期待できる。

\section{5 ）人体への影響}

人は $0.01 \mathrm{ppm} \sim 0.02 \mathrm{ppm}$ というごくわずかなオゾ ンで臭気を感じ， $0.1 \mathrm{ppm}$ で鼻や咽喉に刺激をおぼえ る. $1 \mathrm{ppm} \sim 2 \mathrm{ppm}$ では頭痛, 上気道の渴きを訴元, 5 ppm〜10 ppm では肺水腫に陥る恐れがある. $50 \mathrm{ppm}$ の 1 時間暴露では生命の危険がある。このように, 高 濃度のオゾンは人体に対し毒であるが，低濃度でオゾ ンの臭気を感じるため危険回避は容易であり, 現在ま でオゾンによる大事故の報告は少ない，我が国では産
業衛生学会がオゾンに関する安全基準として，8時間 労働における許容濃度を $0.1 \mathrm{ppm}$ と規定をもうけて いる ${ }^{12)}$.

\section{3。利用分野}

オゾンは食品の殺菌, 脱臭, 鮮度保持 (水産, 畜産, 農産) や衛生環境浄化（上下水道, 住宅, プール, 浴 場, クリーニング, 理容), さらに半導体製造分野での 有機物分解と幅広い分野で利用されている。また, 医 療分野では環境浄化, 器具の消毒, 排水浄化への応用 が試みられている13)。

\section{II. 方 法}

\section{1. 基礎評価}

1）電解質・タンパク質添加試験：オゾン水に対す る透析液排液の影響を観察する目的で電解質とタンパ クの添加試験を行った.オゾン水 $100 \mathrm{~mL}$ に対し $\mathrm{NaCl}$, アルブミンの各溶液を $10 \mathrm{~mL}$ 添加し, 添加前後 のオゾン濃度を比較した. $\mathrm{NaCl}$ は $0.1 \%$ から $10 \%$, ア ルブミンは $0.05 \%$ から $10 \%$ の濃度とした.コントロー ルとして滅菌精製水を用い同様の試験を行った。

2 ) オゾン水消毒施行時の透析装置内オゾン濃度動 態：オゾン水消毒中の透析装置供液側および排液側オ ゾン濃度を測定しオゾン濃度動態を観察した。オゾン 水消毒工程は前水洗 30 分, オゾン水消毒 30 分, 後水 洗 30 分とした。使用した透析装置は TR-322（東レ） である。

3 ）各社透析装置内各部位におけるオゾン濃度動態 およびオゾン水暴露試験：各社透析装置に対しオゾン 水消毒開始後 15 分の供液側, 脱気部, 密閉系入口, 密 閉系内部，密閉系出口，排液側 (図 1) でのオゾン濃度 動態を観察した。また，8時間のオゾン水暴露試験を各 装置扔よびタンパク付着を認める透析装置に対して 行った。検体は 30 分ごとに採取し供液側と排液側のオ ゾン濃度から評価した。使用した透析装置は TR-322, NCU-11（ニプロ），DBB-26（日機装）の3機種であ る。また, 評価した透析装置の中で最もプライミング ボリュームが大きい TR-322 と等量のオゾン水を夕 ンクおよびホース内に貯留しオゾン濃度隇衰を観察し た.

4）精密濾過膜オゾン水暴露試験：透析液清浄化目 的に使用される精密濾過膜に対しオゾン水暴露試験を 行った. 1 日 1 回 22 日間, 精密濾過膜に 8 ppm のオゾ ン水を通過後, 水道水の全濾過を行い濾液中のエンド トキシン濃度を測定した。

使用した精密濾過膜は PEPA 膜（EF-01）, PS 膜 


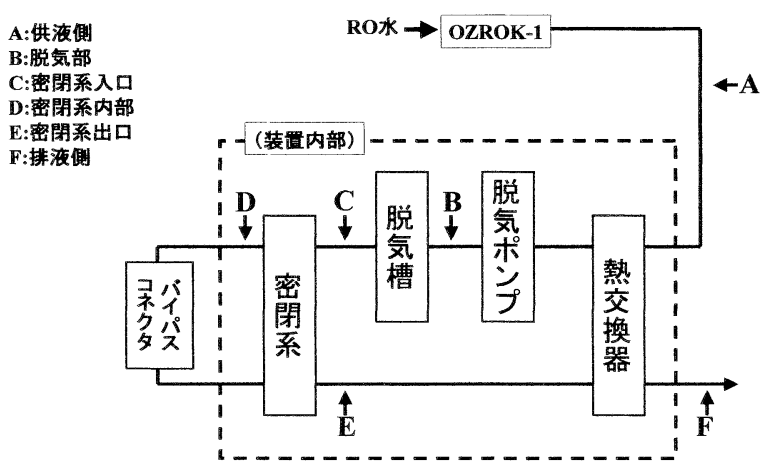

図 1 装置内サンプリングポイント

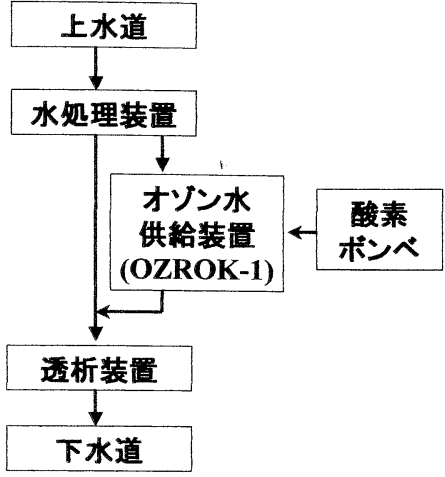

図 2 オゾン水消毒概要

(CF-609), PAN 膜（PNF-1700）である.

\section{2. 臨床評価}

1 ）長期臨床評価：長期臨床使用における検討とし て，オゾン水消毒と次亜塩素酸ナトリウム十酶酸併用 洗浄消毒（併用消毒）との比較を行った。評価期間は 6 週間で検討項目はオゾン水消毒施行前と 1 週目, 6 週 目での透析装置内のタンパク付着, 透析液エンドトキ シン濃度，透析液細菌数，消毒時のオゾン濃度で評価 した。消毒時に装置へ供液したオゾン濃度は 11.6 ppm，透析装置は TR-322 を使用した。オゾン水消毒 とはオゾン水消毒のみを行い，併用消毒とは，月曜日 に次亜塩素酸ナトリウム消毒と酢酸洗浄を，火曜日か ら土曜日までをオゾン水消毒とした方法である。オゾ ン水消毒工程は前水洗，オゾン水消毒，後水洗ともに 30 分. 併用消毒における次西塩素酸ナトリウム消毒酢 酸洗浄工程は前水洗，酸洗净，中水洗，次亜塩素酸ナ トリウム消毒, 後水洗ともに 30 分で行った。サンプリ ングポイントは供液側，脱気部，密閉系入口，密閉系 内部，密閉系出口，排液側の 6 箇所である.

2 ）経済効果：オゾンを用いた消毒法で年間のラン ニングコストの算出を行った。対象薬剤は，次亜塩素 酸ナトリウムとした。

使用機器はオゾン水供給装置として OZROK1 (ワールドメディカル), 測定装置は OZM-01 D（東 京科研）を用いた。

オゾン水消毒システムの概要を図 2 に示す。 OZROK-1 は酸素からオゾンガスを発生させて RO 処 理水へ放出し，オゾン水として透析装置に供液する。

オゾン濃度測定方法は容器に $100 \mathrm{~mL}$ のオゾン水を 採取し電解液を $0.2 \mathrm{~mL}$ 程度添加してから OZM-01D の電極を入れて測定する（図 3 ).

細菌数の測定は標準寒天培地を用いた混釈培養法を 行った

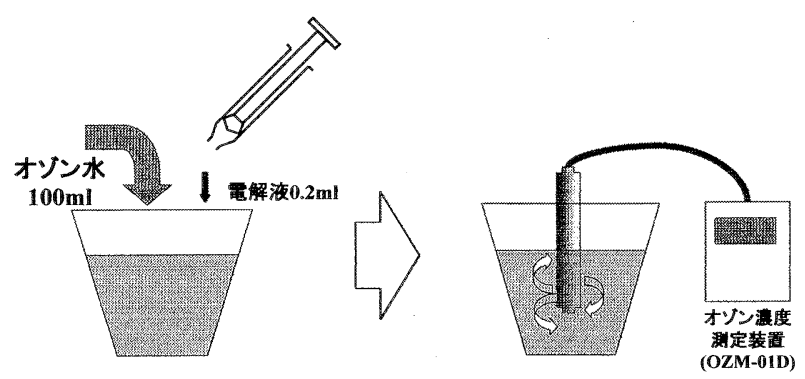

図 3 測定方法

\section{III. 結 果}

1-1）オゾン水中への $\mathrm{NaCl}$ ，アルブミン添加におけ るオゾン濃度変化を図 4 に示す。 $\mathrm{NaCl}$ 添加では $\mathrm{NaCl}$ $10 \%$ の濃度でコントロールに比しオゾン濃度の低下を 認めた。アルブミン添加ではすべての濃度でコント ロールに比しオゾン濃度の低下を認め，アルブミン濃 度 $0.1 \%$ 以上の溶液添加でオゾンは検出されなかっ た。

1-2）透析装置に対しオゾン水を供液した際の装置 内オゾン濃度動態を図 5 に示す。排液側ではオゾン水 供液開始 4 分後からオゾンは検出され10分以降 $5.1 \pm 1.2 \mathrm{ppm}$ で推移した.オゾン水消毒後の後水洗工 程では水洗開始後, 10 分以降から排液側でのオゾン濃 度は検出限界以下となった。なお，透析装置に供液さ れたオゾン濃度は 30 分間, $11 \pm 1.1 \mathrm{ppm}$ と安定してい た。

1-3）各透析装置に打ける装置内オゾン濃度動態を 図 6 に示す。オゾン濃度減衰は密閉系出口で最も強く 現れた。透析装置間では TR-322 は 60\%，NCU-11 は 60\%，DBB-26 は80\%であった。 DBB-26 の減衰率は TR-322，NCU-11 に比し高值を認めた。

8 時間のオゾン水暴露試験結果を図 7 に示す。各装 置上記の結果と同様の減衰率で評価時間内推移した。 


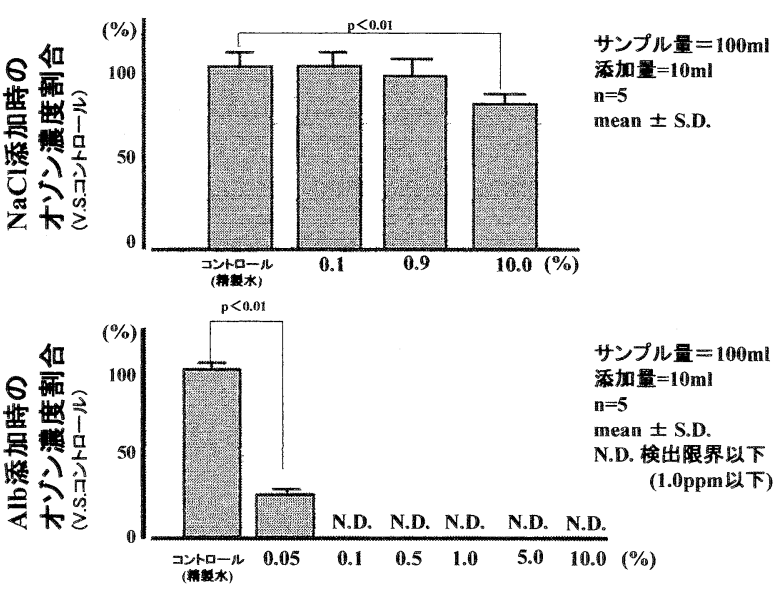

図 $4 \mathrm{NaCl}$ およびAlbumin 負荷とオゾン濃度 変化

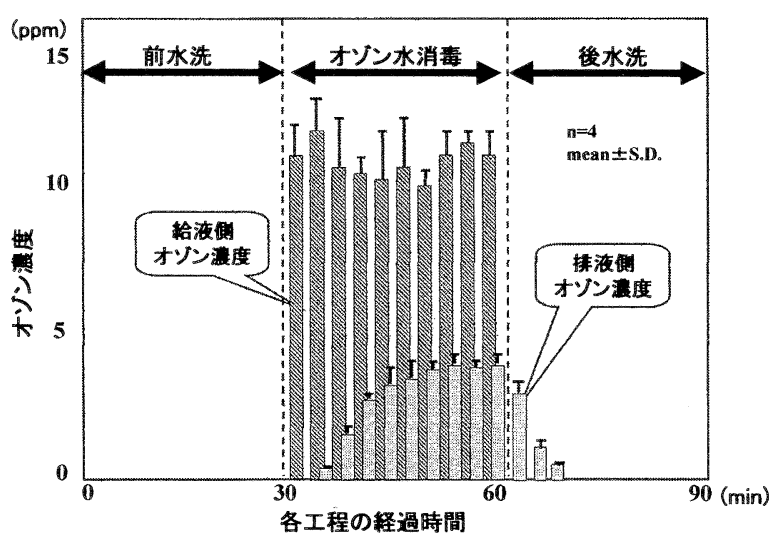

図 5 オゾン水消毒中の供給水側および排液側オ ゾン濃度

同様にタンパク付着の有無による 8 時間オゾン水暴露 試験での，オゾン濃度減衰率はタンパク付着のない透 析装置で $60 \%$, タンパク付着のある装置で $80 \%$ を示し 時間経過によるオゾン濃度上昇はみられなかった。

TR-322 のプライミングボリュームと等量のオゾン 水貯留時のオゾン濃度動態を図 8 に示す。 4 L のオゾ ン水開放， $4 \mathrm{~L}$ のオゾン水密閉，4L のオゾン水ホース 内流水，いずれの条件下でも，オゾン濃度減衰率は， TR-322 通過時の 60\%に比し 18～23\%と低值を認め た。

1-4）精密濾過膜のオゾン水暴露試験の結果を図 9 に示す. PEPA 膜の EF-01 と PS 膜の $\mathrm{CF}-609$ 両者で はオゾン水暴露試験後の水道水全濾過実験において膜 通過濾液中にエンドトキシン濃度の上昇を認めた。 EF-01 ではオゾン水暴露試験により実験配管内に中 空糸様の物質の流出を認めた。そこで EF-01 を直接肉 眼的に観察したところ明らかな膜破壊が確認できた。 PAN 膜の PNF-1700 では膜通過後の溶液中エンドト キシン濃度上昇は認めなかった。

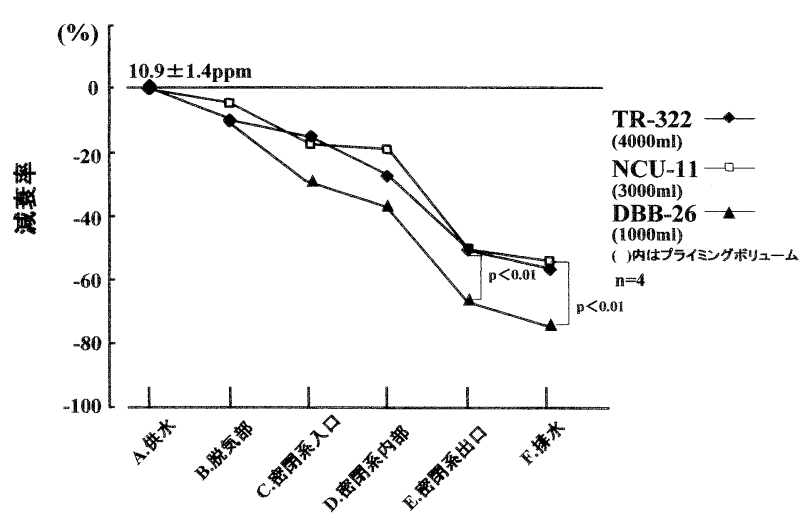

図 6 各装置内オゾン濃度変化

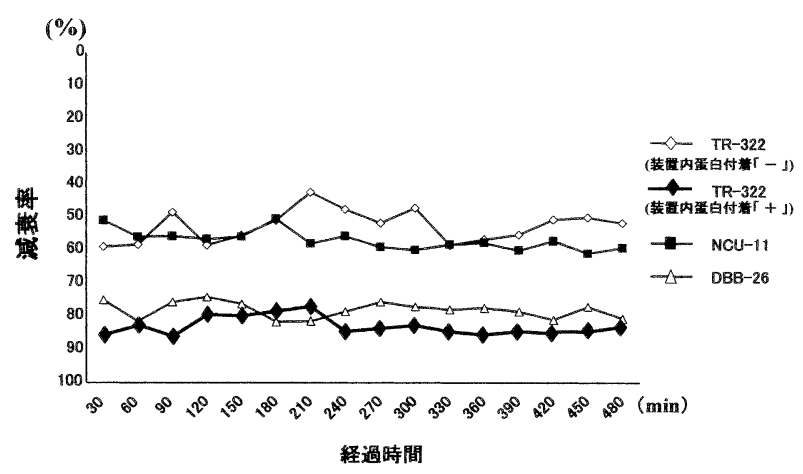

図 7 長時間オゾン暴露試験

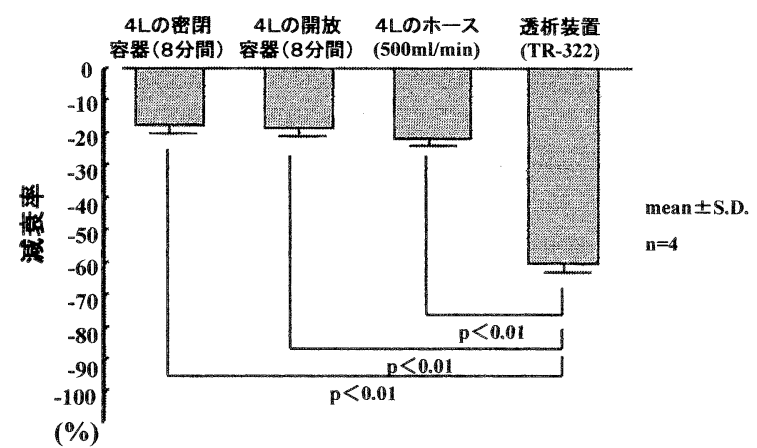

図 8 TR-322 プライミングボリュームと等量の オゾン水濃度変化

2-1）タンパク付着を認めた透析装置の漏血計の写 真を図 10 に示す.下段の併用消毒時の漏血計に比べ上 段のオゾン水消毒 6 週目の漏血計ではタンパク付着が 確認された。この同一時期での透析液清净化に関する 細菌数やエンドトキシン濃度はオゾン水消毒と併用消 毒時に差はなかった。オゾン水消毒のみを長期間施行 した透析装置および併用消毒を施行した装置の装置内 水経路のオゾン濃度減衰を図 11 に示す.オゾン水消毒 6 週目のタンパク付着を認めたバイパスコネクタ後の 密閉系出口部位より下流でオゾン濃度減衰は 1 週目に 比し高值を認めた。併用消毒では 1 週目と 6 週目の才 

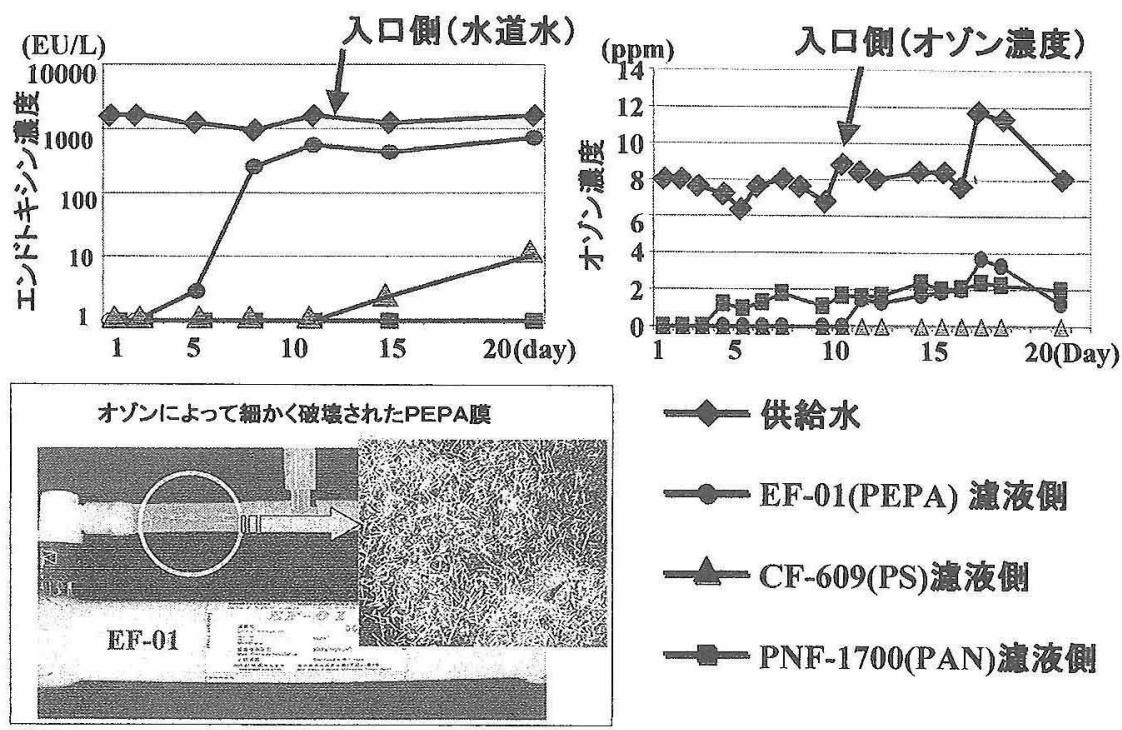

図 9 微粒子除去フィルターへの影響

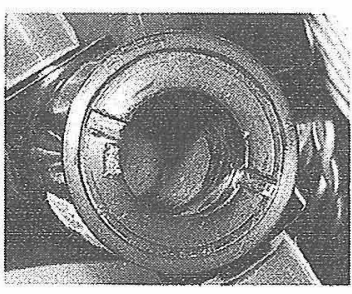

オゾン消密6圈間後

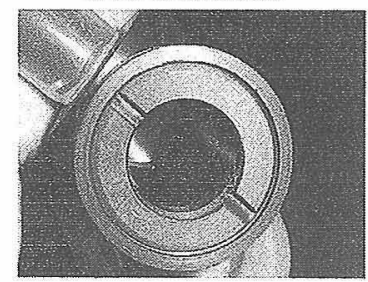

群周消害 6 事間後

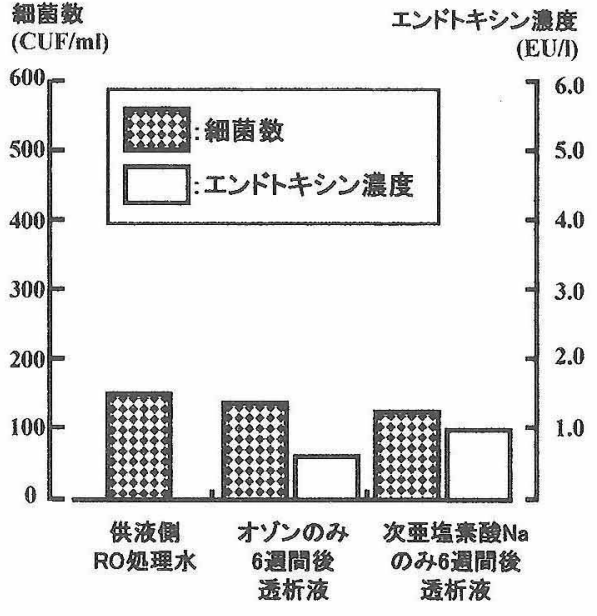

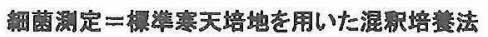

図 10 オゾン消毒長期臨床使用に扔ける装置内状況, エンドトキシン, 細菌数

オソ゚ン水洏㻎

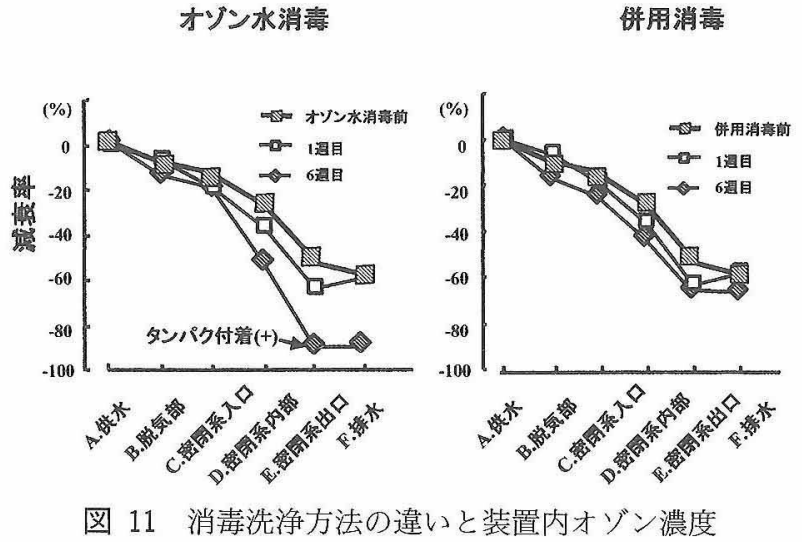

図 11 消毒洗浄方法の違いと装置内オゾン濃度

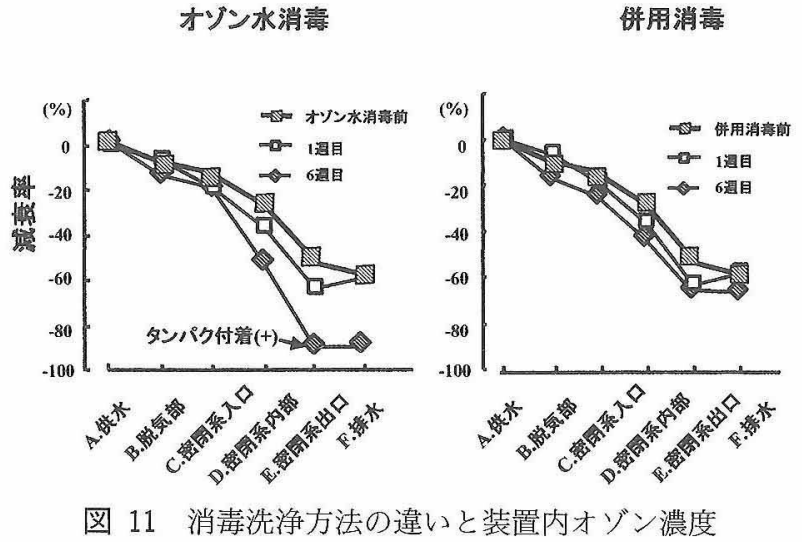

研用消毒 
ゾン濃度減衰に差は認めなかった。

2-2）年間ランニングコストの試算結果を表 2 に示 す。次亜塩素酸ナトリウム使用時と比べ薬品代で $83 \%$ ，上下水道代で $71 \%$ のコストダウン，あわせて年 間 70\%のコストが節約できることが試算された。

\section{IV. 考察}

血液透析施設は, 他の医療施設と異なり大量の透析 液, 消毒・洗浄剤を排出し地球環境にダメージを与え ている可能性は否定できない。これは, 日々血液透析 療法に携わっているわれわれスタッフにとって無視で きない問題である。それゆえ, 環境污染を考慮した消 毒剤や消毒法の開発が試みられている。そこでわれわ れは, 消毒効果発現後速やかに分解し環境への影響が 少ないとされるオゾンを用い血液透析装置の消毒を施 行し，オゾンの有用性を評価した。 反応性の速いオゾ ンを用いて透析装置の消毒を行う場合, 消毒効果発現 部位でのオゾン濃度をいかに維持できるかを考慮しな ければならない。.また, 装置内で消毒効果を発揮する ためには，使用するオゾン濃度をいかに設定するかが 重要となる。そのためにも装置内でのオゾン濃度動態 の推移，すなわち装置配管内のプライミングボリュー ムや材料, 装置配管内に残留されうる電解質や有機物 を観察する必要がある。そこでわれわれはオゾン濃度 の減衰動態に対する基礎的検討を行った。

添加試験の結果より電解質やタンパク質の存在でオ ゾンは減衰することが確認できた。 そのため，オゾン の効果を十分に発揮させるためには透析装置の前水洗 を十分に行う必要がある。透析装置配管内に有機物等 の反応促進物質がない場合においてオゾン濃度は 50〜 60\%の減衰を認めた。その減衰率は透析装置間で 異なり, 特にDBB-26 で減衰が大きいのは複式ポンプ 等による圧力損失が他の 2 機種に比べ大きいためと推 測される。透析装置と等量の各減衰実験結果を合わせ て考えると, 透析装置内の減衰はバッチ式の基礎実験 と異なり単に自然崩壊のみに起因せず透析装置内に残 留する有機物の存在や圧力変化, 空気に接触する構造 体, などが影響していると考えられる。オゾン水消毒 を効率的に行うには透析装置の機構, 設計変更を行う 必要がある。

一方，タンパク付着を認めた装置に対して 8 時間と いう長時間のオゾン暴露において, 排液側のオゾン濃 度の上昇もなく, 透析装置内のタンパクも除去できな かった。添加試験やタンパク付着時の減衰試験から考 えると，オゾンは有機物に対し極めて激しい減衰を示
すことがわかる.タンパク付着を想定した供液オゾン 濃度および消毒時間を思案しなければならない。

透析液清浄化を目的として使用される精密濾過膜に 対する暴露試験で大幅なオゾン濃度減衰と膜破壊を認 めた。このことからオゾン水消毒を用いる場合, 今回 膜破壊を認めた精密濾過膜の使用は禁忌となる。今後 はさまざまな膜種に対して同様の評価を行い使用可能 な膜を明確にしなければならない.

臨床使用においてオゾン水単体の消毒でも通常の消 毒方法と比較してエンドトキシン濃度, 細菌数に差が みられなかった。しかし，オゾン水単体の消毒法では 使用 6 週目でタンパク付着を確認したが週 1 回の次亜 塩素酸ナトリウムと䣷酸洗浄消毒を併用することで装 置内にタンパク付着を認めず良好な結果が得られた。

ランニングコストの試算においてオゾン消毒は年間 約 7 割の費用が削減でき，従来の次亜塩素酸ナトリウ ム消毒より経済的に優れていることを確認した。

今回，われわれの行ったオゾン水消毒のモデルにお いて，オゾン水単体の消毒では除タンパクの面で限界 を感じる結果となった。しかし, オゾンの問題点, 減 衰傾向の認知, さらに次亜塩素酸ナトリウムの使用量 削減，低コスト化の可能性を示唆できたことは十分な 収穫といえる。今後もオゾン水流入時間の延長, 装置 内の圧力変化を少なくするなどの構造変更によるオゾ ン減衰防止，除タンパク剤や他の薬剤との併用などを 検討する必要がある。オゾンを透析分野に応用するこ とは透析排水による環境破壊を防止する一手段となり 得る方法であると考える。

\section{結語}

血液透析装置の消毒剤としてオゾンを用いる場合, いくつかの条件下でオゾン濃度の減衰, すなわち消毒 効果が低下することが確認できた。 しかし, 透析装置 の機構, 設計の変更や他の消毒剤との組み合わせ, 洗 浄 ·消毒工程時間の変更などにより解決可能と考えら れる。

地球環境污染や，経済性などをふまえて考慮すると オゾンを用いた血液透析装置の消毒は有用と考えられ た。

\section{文献}

1）星野敏久：3. 透析装置の消毒方法. 透析療法, p 24-25, 中外医学社, 東京, 1997

2) 峰島三千男：ダイアライザにおける内部濾過発生のメ カニズム。臨牀透析 18：7-12, 2002 
3）阿部 薰, 椎名 充, 星野正信, 山本明広, 芝本 隆, 秋葉 隆: 水道水に含まれるエンドトキシン, ベータ グルカンのハイフラックス膜通過の評価。透析会誌 31:1273-1278, 1998

4）大貫順一：滅菌・消毒・洗浄剤の使用後廃棄における 問題.クリニカルエンジニアリング 9：1105-1115, 1998

5）中澤了一：医療廃棄物としての滅菌・消毒・洗浄剤。 クリニカルエンジニアリング 13：1128-1133， 2002

6）三浦 明, 新井浩之, 鈴木利昭：透析ラインの洗浄化 と問題点。透析会誌 $33: 255-258,2000$

7）星野敏久, 海老沢秀夫, 金子岩和, 峰島三千男, 佐中 孜，阿岸鉄三，太田和夫：透析装置の消毒方法と透析 液の清浄化対策。クリニカルエンジニアリング 8：
420-426, 1997

8）出口冨雄：オゾンで水がよみがえる. (1)クリーンな気 体オゾンとは, 1993, 東洋経済新報社

9）都田昌之：第 2 章機能水の分類，オゾン溶解水. p 4144, 工業調查会, 東京, 2002

10）赤堀幸男, 村上篤司, 星 昭二：オゾンの殺菌効果と 院内感染予防への応用。日集中医誌 $7: 3-11,2000$

11）伊藤泰郎：耐オゾン性材料, オゾンの不思議。 p 57, 講 談社, 東京, 1999

12）杉光英俊：7.3.1 作業環境許容濃度，オゾンの基礎と 応用. p 177-179, 光琳, 東京, 1996

13）杉光英俊：第 9 章オゾンの応用例，オゾンの基礎と応 用. p 213-238, 光琳, 東京, 1996 